Joanna Kazimiera SKULSKA ${ }^{1}$

\title{
TEORIA ARGUMENTACJI DOUGLASA WALTONA W ZASTOSOWANIU DO BADAŃ Z ZAKRESU KOMUNIKACJI POLITYCZNEJ ${ }^{2}$
}

\begin{abstract}
Celem niniejszego artykułu jest metodologiczna ocena użyteczności narzędzi (w postaci schematów argumentacji), jakich dostarcza współczesna teoria argumentacji Douglasa N. Waltona w zastosowaniu do badań z zakresu komunikacji politycznej. Jest to zatem próba odpowiedzi na pytanie: czy zaproponowane przez Douglasa N. Waltona schematy argumentacji są możliwą do zastosowania w badaniach z zakresu komunikacji politycznej (analizach wypowiedzi argumentacyjnych wyrażonych w języku naturalnym) alternatywą dla nieadekwatnych i nieskutecznych w tym zakresie narzędzi, dostarczanych przez logikę formalną? W tym celu opisano kluczowe pojęcia, stanowiące bazę dla niniejszych rozważań, m.in. podejście dialogowe, reprezentowane przez Jürgena Habermasa, będące jednym z kluczowych paradygmatów badań, dotyczących sposobów komunikowania politycznego oraz niemonotonicznego charakteru nauk społecznych. Dialogiczna struktura komunikacji stanowi fundament wypowiedzi argumentacyjnych, co umożliwia wykorzystanie schematów argumentacji jako narzędzi metodologicznych do przeprowadzania badań z tego zakresu, zaś niemonotoniczność jest trzonem współczesnych koncepcji, związanych z teorią argumentacji, w tym także waltonowskiej koncepcji schematów argumentacji. Działania te doprowadzą w konsekwencji do próby wykazania, że zaproponowane $\mathrm{w}$ niniejszym artykule analizy argumentacyjne w obszarze zachowań komunikacyjnych mogą mieć znaczący wpływ na rozwój metodologii badań politycznych oraz weryfikację dotychczasowych sposobów ich interpretacji. Przeprowadzenie badań i analiz argumentacyjnych w obszarze politycznych zachowań komunikacyjnych ma duże znaczenie dla zrozumienia istniejącej rzeczywistości politycznej. Zastosowanie wyników badań współczesnej teorii argumentacji do badania dyskursu naturalnego politologii znacząco wpłynie na rozwój metodologii badań politologicznych. Zwróci uwagę na problem nieuniknionego wartościowania, podejmowania decyzji oraz niemonotoniczności wyciąganych wniosków. Teoria argumentacji jest aktualnie bardzo burzliwie rozwijającą się nauką i podsuwa wiele rozwiązań w tej dziedzinie.

Słowa kluczowe: logika nieformalna, dyskurs naturalny, metodologia badań politologicznych, rozumowania niemonotoniczne.
\end{abstract}

\section{WSTĘP}

Jednym z kluczowych nurtów współczesnych badań nad argumentacją jest tzw. logika nieformalna (informal logic). Wśród jej czołowych przedstawicieli należy wymie-

\footnotetext{
${ }^{1}$ Mgr Joanna Kazimiera Skulska, Wojskowa Akademia Techniczna w Warszawie, Wydział Cybernetyki, ul. gen. Sylwestra Kaliskiego 2, 00-908 Warszawa 49, tel.: (22) 68395 24, e-mail: joannaskulska@o2.pl

${ }^{2}$ Niniejszy tytuł jest tożsamy z tytułem pracy doktorskiej Joanny Skulskiej, która stanowiła inspirację dla powstania niniejszego artykułu.
} 
nić takich uczonych, jak J. Anthony Blair, Ralph H. Johnson czy Douglas Walton ${ }^{3}$. Motywacją do stworzenia tej koncepcji była chęć zaangażowania narzędzi logiki do zastosowań, takich jak analiza i ocena argumentacji prowadzonej w życiu codziennym, w politycznych debatach, prawnych sporach, czy społecznych komentarzach charakterystycznych dla gazet, telewizji, internetu. Charakterystyczną cechą tego typu argumentów jest po pierwsze - ich dialogiczna struktura, po drugie - niemonotoniczny (podważalny) charakter. Logika nieformalna dostarcza metodologicznych narzędzi w postaci schematów argumentacji, które umożliwiają tego typu analizę. Schematy argumentacji obejmują dedukcyjne formy rozumowania, jak modus ponens, $\mathrm{i}$ indukcyjne formy, jak argument ze zgromadzonych zbiorów danych do statystycznego wniosku wynikającego z tych danych. Ten rodzaj rozumowania wspomaga wnioskowanie w wypadku jego niekompletności, umożliwia domyślenie się niewiadomych danych. Stanowi on zatem idealne narzędzie wspierające, stosowaną w naukach społecznych, analizę ,języka" w danym dyskursie naturalnym.

Podobnie jak wszystkie nauki o społeczeństwie, tak i politologia ma indukcyjne pochodzenie ${ }^{4}$. Metody, jakimi posługuje się politologia, osadzone są zatem we współczesnym pojęciu rozumowań niepewnych (nonmonotonic, defeasible, presumptive $)^{5}$. Rozumowania te pod pewnym względem stanowią odpowiednik reguł inferencji monotonicznych systemów dedukcyjnych z jedną jednak różnicą. Wniosek wyprowadzony na podstawie rozumowania niemonotonicznego nie jest przyjęty z całkowitą pewnością. Rozszerzenie zbioru przesłanek o jakieś nowe informacje zobowiązuje (commit) nas do wycofania poprzedniego wniosku i przyjęcia nowego. Rozumowania te opierają się nie na przesłankach koniecznych, ale na przesłankach prawdopodobnych. Przesłankach, które opisują najczęściej (zazwyczaj) występującą sytuację, przesłanki te są zazwyczaj (choć nie zawsze) prawdziwe.

Podstawę poznania politologicznego stanowią materiały źródłowe. Dostarczają one określonych informacji nazywanych wiedzą źródłową. Z punktu widzenia poznania politologicznego źródłem jest każdy utrwalony i zachowany ślad myśli, działania oraz aktywności ludzkiej służący do jego deskrypcji, eksplantacji oraz przewidywania związanej z nim rzeczywistości politycznej ${ }^{6}$. Owe materiały źródłowe, które stanowią podstawę poznania politologicznego, są mocno związane ze zjawiskiem komunikacji międzyludzkiej. Badania nad dyskursem są związane z przekonaniem, „że rzeczywistość

\footnotetext{
${ }^{3}$ Zob. R.H. Johnson, T. Blair, Logical Self-Defence, Toronto 1977; D. Walton, Informal Logic: A Handbook for Critical Argumentation, Cambridge University Press, New York 1989.

${ }^{4}$ Indukcja (łac. inductio - wprowadzenie) to typ rozumowania redukcyjnego. Określa się je jako wnioskowanie „od szczegółu do ogółu”, tj. wnioskowanie z prawdziwości racji (wniosków w szerokim znaczeniu tego słowa) o prawdziwości następstw (przesłanek w szerokim znaczeniu tego słowa). J.M. Bocheński, Wspótczesne metody myślenia, ANTYK, Komorów 2009; T. Jemioło, A. Dawidczyk, Wprowadzenie do metodologii badań bezpieczeństwa, Warszawa 2008, s. 22

${ }^{5}$ H. Prakken, G. Vreeswijk, Logics for Defeasible Argumentation, Handbook of Philosophical Logic, vol. 4, Kluwer Academic Publishers, Dordrecht 2002, s. 219-318.

${ }^{6}$ A.J. Chodubski, Wstęp do badań politologicznych, Wydawnictwo Uniwersytetu Gdańskiego, Gdańsk 2004.
} 
jest konstruowana w procesach komunikacyjnych"7. W rozwoju badań nad komunikowaniem politycznym odnaleźć można różne podejścia teoretyczne. Podejścia te akcentują różnorodne elementy, takie jak dialog, strategia, zachowania, system, a nawet konstrukcja rzeczywistości społecznej. Jednym z obowiązujących współcześnie podejść teoretycznych do komunikowania politycznego jest podejście dialogowe. Stanowi ono wypośrodkowanie koncepcji interakcjonizmu symbolicznego (intersubiektywizm komunikowania) i interakcjonizmu strategicznego (prakseologia komunikowania) ${ }^{8}$. Model dialogowy opiera się na idei konsensusu wypracowanego w drodze debaty publicznej. Jest przedłużeniem tradycji filozoficznej wywodzącej się od Arystotelesa, zakładającej, że ludzie (obywatele) mogą rozważyć dzielące ich opinie w dyskusji opartej na argumentach po to, aby ustalić wspólny punkt widzenia ${ }^{9}$.

\section{WPROWADZENIE DO BADAŃ NAD WYKORZYSTANIEM TEORII ARGUMENTACJI DO ANALIZY KOMUNIKACJI POLITYCZNEJ}

Politologia $w$ badaniach wykorzystuje dorobek naukowy innych dyscyplin, co umożliwia łączenie ze sobą osiągnięć uzyskanych niezależnie. Weryfikacji wymagają dotychczasowe sposoby interpretacji znaczenia teorii argumentacji dla badań typu politologicznego. Ostatnie prace z dziedziny teorii argumentacji wykazały, że argumentacja oferuje potężne środki do rozwiązania wspomnianych wcześniej problemów przez odejście od czysto dedukcyjnych podejść monotonicznych do rozumowania i ku przypuszczalnym, podważalnym technikom ${ }^{10}$. Takie rozumowanie musi także być przedstawione $\mathrm{w}$ formie dialogicznej, w formie, która jest odpowiednia do używanej przez ludzi. Współcześnie w teorii argumentacji dominują normatywne modele technik w dwóch ujęciach - argumentacyjnym i dialogowym. W pierwszym z nich dąży się do sformułowania skutecznych (przekonujących) schematów argumentacji ${ }^{11}$, przy czym duży nacisk kładzie się na zapewnienie poprawności stosowania tych schematów. W ujęciu dialogowym formułuje się reguły dyskusji. Na polskim gruncie można zaobserwować rosnące w ostatnich latach zainteresowanie tematyką strategii retorycznych i argumentacyjnych, przy czym dominują tu trzy tendencje: historyczno-teoretyczna (np. Ziomek czy Korolko), retoryki stosowanej (np. Załęska czy Warchał) oraz najbardziej rozwinięte podejście teorio-argumentacyjne (np. Hołówka, Marciszewski, Szymanek, Tokarz) ${ }^{12}$.

\footnotetext{
${ }^{7}$ Por. A. Grzymała-Kazłowska, Socjologicznie zorientowana analiza dyskursu na tle wspótczesnych badań nad dyskursem, „Kultura i Społeczeństwo” XLVIII/1 (2004), s. 13; B. Jabłońska, Krytyczna analiza dyskursu: refleksje teoretyczno-metodologiczne, „Przegląd Socjologii Jakościowej” 2/1 (2006), s. 57.

${ }^{8}$ B. Dobek-Ostrowska, R. Wiszniowski, Teoria komunikowania publicznego i politycznego, Astrum, Wrocław 1999, s. 110.

${ }^{9}$ J. Gerstle, Le communication politique, PUF, Paris 1992, s. 32.

10 Zob. D. Carbogim, D. Robertson, J. Lee, Argument-based Applications to Knowledge Engineering, „Knowledge Engineering Review” 15/2 (2000), s. 119-149.

${ }^{11}$ Por. np. Ch. Perelman, L. Olbrechts-Tyteca, Traite de l'argumentation - la nouvelle rhetorique, PUF, Paris 1958.

12 T. Hołówka, Blędy, spory, argumenty, UW, Warszawa 1999; W. Marciszewski, Podstawy logicznej teorii przekonań, PWN, Warszawa 1972; W. Marciszewski, Sztuka dyskutowania, 4 wyd., Aleph, Warszawa 1996; K. Szymanek, Sztuka argumentacji, Stownik terminologiczny,
} 
Również badania nad komunikowaniem politycznym są na bardzo zaawansowanym poziomie. Od połowy lat pięćdziesiątych XX w. powstało wiele publikacji poruszających tego typu problematykę. Badania prowadzone są głównie w ramach dziedzin naukowych, takich jak: komunikowanie masowe (np. J. Blumer, M. Gurevitch, D. McQuail, D. Swanson, R. Negrine, B. McNair czy P. Zemor), socjologia i politologia (np. P. Norris, J. Gerstle, M. Wheeler, D. Watts, R. Denton, G. Woodward, D. Nimmo). W polskiej literaturze naukowej tematyka komunikowania politycznego jest dość rzadko podejmowana, a nieliczne opracowania pisane są przez autorów reprezentujących dziedziny politologii czy socjologii (np. P. Pawelczyk, D. Pionek, J. Muszczyński, G. Ulicka, czy R. Eiszniowski). W literaturze przedmiotu brakuje opracowań, które zawierałyby całościowy wgląd $\mathrm{w}$ tę dziedzinę życia politycznego będącą jednym $\mathrm{z}$ istotnych obszarów funkcjonowania rzeczywistości politycznej. Konieczne jest, aby badane zagadnienia ujęte zostały kompleksowo, gdyż przedmiotem analizy jest całokształt systemu politycznego. Kompleksowe badania zapewnia rzetelna analiza uwzględniająca prawidłowe zastosowanie metodologii badawczej, w tym także analizy dyskursu naturalnego typu argumentacyjnego. Ciągle zauważalny jest deficyt badań dotyczący argumentacyjnej analizy ,języka” nauk społecznych osadzonej w analizie dyskursu naturalnego.

Do pełnych badań nad dyskursem niezbędne jest przeprowadzenie jakościowej analizy treści zwracającej uwagę na strategię argumentacji, poprawność jej użycia, nie tylko analizę pojęć, ale również zachodzących między nimi relacji. Konieczne jest, aby badane zagadnienia ujęte zostały kompleksowo, ponieważ przedmiotem analizy jest całokształt systemu politycznego. Kompleksowe badania zapewnia rzetelna analiza uwzględniająca prawidłowe zastosowanie metodologii badawczej, ustalenie występujących wzorców, wykrycie sprzeczności, ich źródeł oraz przyczyn, a także próba wyciągnięcia wniosków i przewidywań na przyszłość. Logika nieformalna dostarcza metodologicznych narzędzi w postaci schematów argumentacji, które umożliwiają tego typu analizę. Wymagałoby to korelacji współczesnej teorii argumentacji, ze szczególnym uwzględnieniem koncepcji schematów argumentacyjnych Douglasa Waltona ze stosowanymi w naukach społecznych, politycznych podstaw metodologicznych zmierzających ku analizie ,języka” nauk społecznych. Teoria schematów argumentacji Waltona jest jednym z bieżących nurtów badań logiki nieformalnej. Motywacją do stworzenia tej koncepcji była chęć zaangażowania narzędzi logiki do zastosowań, takich jak analiza i ocena argumentacji prowadzonych w życiu codziennym, w politycznych debatach czy społecznych komentarzach. Charakterystyczną cechą tego typu argumentów jest po pierwsze - ich dialogiczna struktura, po drugie - niemonotoniczny (podważalny) charakter.

\section{NARZĘDZIA ANALIZY, JAKICH DOSTARCZA TEORIA}

\section{ARGUMENTACJI}

Do zrozumienia struktury teorii argumentacji niezbędne jest zaprezentowanie jej podstawowych pojęć i metod, jakie rozwinęły się do dziś. W literaturze wyróżnione są cztery zadania podejmowane przez teorię argumentacji: identyfikacja, analiza, ocena i

PWN, Warszawa 2001; M. Tokarz, Argumentacja, Perswazja, Manipulacja (Argumentation, Persuasion, Manipulation), GWP, Gdańsk 2006. 
inwencja (invention $)^{13}$. Zadanie identyfikacji polega na zidentyfikowaniu $\mathrm{w}$ tekście dyskursu przesłanek i wniosku argumentu ${ }^{14}$. Częścią tego zadania jest także określenie, czy znaleziony w tekście dany argument pasuje do znanej formy argumentu o nazwie „schemat argumentacji”. Celem analizy jest standaryzacja, czyli wyodrębnienie w wypowiedzi argumentacyjnej zawartych w niej przesłanek oraz wniosku argumentu. Aby dokonać prawidłowej standaryzacji, niezbędne jest dokonanie szczegółowej analizy struktury argumentu. Funkcją oceny jest ustalenie, czy argument jest słaby czy silny poprzez ogólnie stosowane kryteria. Jednym z najważniejszych narzędzi aktualnie wykorzystywanych do wspierania zadania analizy i oceny argumentów jest diagram argumentacji. Metoda diagramów polega na wizualnej reprezentacji struktury oraz schematów argumentacji. Ostatnim i zarazem najmniej rozwiniętym zadaniem teorii argumentacji, na jakie wskazuje literatura, jest zadanie inwencji. Polegać ono ma na budowaniu nowych argumentów, które mogą być wykorzystane do udowodnienia konkretnego wniosku. Schematy mają zatem na celu budowanie nowych argumentów, które moga być wykorzystane do udowodnienia konkretnego wniosku. Idealnie jednak nadają się również do funkcji analizy oraz oceny argumentów.

Schematy argumentacji są to rozumowania oparte na toposach, czyli funkcjach zdaniowych uznawanych za powszechnie ważne ${ }^{15}$, oraz współczesnym pojęciu rozumowań niepewnych (nonmonotonic, defeasible, presumptive) ${ }^{16}$. Schematy argumentacji opierają się na przesłankach prawdopodobnych. Przesłankach, które opisują najczęściej występującą sytuację. Takie rozumowanie jest przypuszczalne i podważalne. Ten rodzaj rozumowania jest tylko prawdopodobny i często odnosi się do warunków niepewności i braku wiedzy. Domniemane rozumowanie wspiera wnioskowanie w warunkach niekompletności przez umożliwienie domyślenia się niewiadomych danych. Rozumowanie to jest podważalne w tym sensie, że wniosek może zostać wycofany lub zmieniony $\mathrm{w}$ wypadku, gdy znane (ale niepewne) dane okażą się wadliwe ${ }^{17}$. Arthur Hastings ${ }^{18} \mathrm{w}$ tezach doktoratu (1963) zaprezentował systematyczną analizę wielu najpopularniejszych schematów $^{19}$. Sam schemat, w podejściu Hastingsa, jest określony poprzez wskazanie formy przesłanek i wniosków w każdego rodzaju argumentach. Hastings wyróżnia jedną szczególną przesłankę w każdym schemacie (zgodnie z wskazaniami Toumlina ${ }^{20}$ ), która mogłaby być postrzegana jako uogólnienie lub zasada, prowadząca inne założenie lub przesłanki do wniosku. Taki nakaz jest zazwyczaj niepewnym uogólnieniem i pod-

\footnotetext{
${ }^{13}$ Argumentation Theory: A Very Short Introduction, Argumentation in Artificial Intelligence, eds. I. Rahwan, G. Simari, Springer, Berlin 2009, s. 1-24.

${ }^{14} \mathrm{Z}$ argumentem (łac. argumentum) mamy do czynienia, gdy ,jako uzasadnienie poglądu $\mathrm{T}$ przedstawione są jakieś zdania P1, P2, ..., Pn; zdania te nazywa się przesłankami, zaś zdanie T - konkluzją argumentu"; K. Szymanek, Sztuka argumentacji. Slownik terminologiczny, Wydawnictwo Naukowe PWN, Warszawa 2004.

${ }^{15}$ Arystoteles, Retoryka, PWN, Warszawa 2008.

${ }^{16}$ H. Prakken, G. Vreeswijk, op. cit., s. 219-318.

17 J. Fox, D.S. Subrata, Safe and Sound: Artificial Intelligence in Hazardous Applications, Cambridge Mass MIT Press, Cambridge 2000.

18 A.C. Hastings, A Reformulation of the Modes of Reasoning in Argumentation, Ph.D. Dissertation, Northwestern University, Evanston, III 1963.

${ }^{19}$ Ibidem.

${ }^{20}$ S. Toulmin, The Uses of Argument, Cambridge University Press, Cambridge 1958.
} 
lega weryfikacji. Dlatego też do każdego schematu Hastings podaje odpowiedni zestaw krytycznych pytań. Walton $(1996)^{21}$ zidentyfikował około 31 (w zależności od sposobu ich liczenia) schematów argumentacji dla typowych niepewnych rozumowań. Podążając, za modelem Hastingsa, Walton do schematów dołączył zestaw krytycznych pytań, którego zadaniem jest dopasowanie i testowanie struktury schematu argumentu. Zadawanie krytycznych pytań oraz udzielanie na nie odpowiedzi to forma określania rodzaju struktury w każdej z obu stron współdziałających ze sobą. Jeśli argument przedstawiony przez zwolennika spełnia wymagania systemu, a przesłanki są do zaakceptowania przez respondenta, to respondent jest zobowiązany do zaakceptowania wniosku. Taka akceptacja lub zobowiązanie, jak to jest często nazywane, jest $\mathrm{w}$ dialogu tymczasowe. Jeśli respondent zada jedno z krytycznych pytań pasujących do schematu, a orędownik nie oferuje odpowiedniej odpowiedzi, argument jest podważalny. Widać zatem, że podważalność jest związana ze strukturą dialogu.

Te dwa elementy razem - schemat argumentacji i pasujące krytyczne pytania - są używane do oceny danego argumentu w konkretnym wypadku (w odniesieniu do kontekstu dialogu, w których argument jest zastosowany). Według standardowego podejścia do oceny argumentu w nieformalnej logice podany argument musi być oceniany w świetle trzech czynników: akceptowalności przesłanki, znaczenia przesłanek dla wniosku oraz oceny, czy przesłanki zapewniają wystarczający powód do przyjęcia wniosku.

\section{PRZYKLADOWA ANALIZA}

W tej części artykułu pokazano, w jaki sposób metoda diagramów oraz schematy argumentacji Waltona wspierają analizę argumentacji. Analizę przeprowadzono na przykładzie wypowiedzi opublikowanej na oficjalnej stronie partii „Twój Ruch”: „Najwyższa Izba Kontroli odkryła Amerykę, stwierdzając, że szkolne programy profilaktyki narkomanii są nic niewarte. Pomylili się w jednym - szkolne pogadanki są nie tylko nieskuteczne, ale również szkodliwe. Jak w praktyce wygląda szkolna «profilaktyka»?

Do lokalnego gimnazjum przychodzi policjantka w podeszłym wieku, która czytając $\mathrm{z}$ kartki straszy dzieciaki, że wszystkie nielegalne narkotyki to zło i prosta droga do śmierci. W tym samym czasie z ostatniej ławki dobiega chichot upalonych małolatów. Dzięki prohibicji i braku regulacji państwa, byli w stanie bez problemu kupić zanieczyszczoną marihuanę przed lekcjami. Jedyną nauką, jaką wyniosą ze szkolnych pogadanek, jest przekonanie o hipokryzji i zakłamaniu «dorosłych». Jedną z głównych przyczyn popularności browna (heroiny do palenia) w ubiegłej dekadzie, było właśnie wrzucanie do jednego worka stosunkowo nieszkodliwej marihuany $\mathrm{z}$ silnie uzależniającymi substancjami, takimi jak heroina. Ustawa wskazuje jako główne narzędzie przeciwdziałania narkomanii właśnie profilaktykę, której - jak dobitnie pokazuje ten raport - w Polsce praktycznie nie ma. Cała uwaga i środki skupione zostały na przepisach karnych i represjach, które zgodnie z literą prawa winny stanowić jedynie uzupełnienie programów profilaktycznych. Twój Ruch opowiada się za rzetelną, popartą danymi empirycznymi profilaktykę prowadzoną od najwcześniejszych lat.

${ }^{21}$ D. Walton, Argumentation Schemes for Presumptive Reasoning, LEA, New York 1996. 
Priorytetem musi być skuteczność i zdrowie publiczne, nie zaś obłudna moralność i ideologia"22.

Temu fragmentowi opublikowanej wypowiedzi można nadać różną reprezentację wizualną w zależności od interpretacji słów dokonanej przez konkretnego analizującego. W artykule przedstawiono jedną z propozycji standaryzacji tej wypowiedzi.

\section{Standaryzacja przykładu}

WNIOSEK: Programy profilaktyki narkomanii są nic niewarte, są nie tylko nieskuteczna, ale również szkodliwe.

PRZESŁANKA 1: Do lokalnego gimnazjum przychodzi policjantka w podeszłym wieku, która czytając z kartki straszy dzieciaki, że wszystkie nielegalne narkotyki to zło i prosta droga do śmierci. W tym samym czasie z ostatniej ławki dobiega chichot upalonych małolatów. Dzięki prohibicji i braku regulacji państwa byli w stanie bez problemu kupić zanieczyszczoną marihuanę przed lekcjami. Jedyną nauką, jaką wyniosą ze szkolnych pogadanek, jest przekonanie o hipokryzji i zakłamaniu ,dorosłych”.

PRZESLANKA 2: Jedną z głównych przyczyn popularności browna (heroiny do palenia) w ubiegłej dekadzie było właśnie wrzucanie do jednego worka stosunkowo nieszkodliwej marihuany z silnie uzależniającymi substancjami, takimi jak heroina.

PRZESŁANKA 3: Ustawa wskazuje jako główne narzędzie przeciwdziałania narkomanii właśnie profilaktykę, której - jak dobitnie pokazuje ten raport - w Polsce praktycznie nie ma.

PRZESŁANKA 4: Cała uwaga i środki skupione zostały na przepisach karnych i represjach, które zgodnie z literą prawa powinny stanowić jedynie uzupełnienie programów profilaktycznych

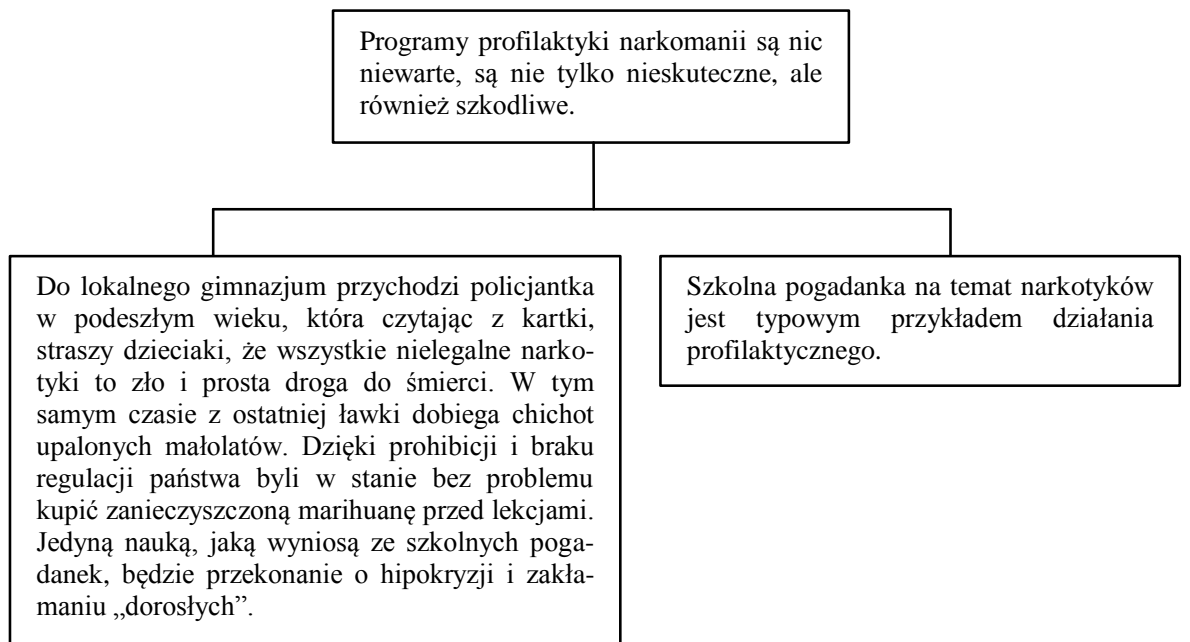

Rys. 1. Diagram - przesłanka 1, schemat z przykładu

22 http://twojruch.eu/wiadomosci/nik-profilaktyka-narkotykowa-w-szko-ach-nie-istnieje (dostęp: 20.10.2013) 
Na rysunku 1 zaprezentowano wizualną reprezentację, w jaki sposób przesłanka pierwsza doprowadza do wniosku głównego. Rozumowanie to wpisuje się w Waltonowski schemat z przykładu ${ }^{23}$ :

\section{Przesłanka: W tej sytuacji k ma własność $F$ oraz własność $\mathbf{G}$}

[w tej sytuacji - czyli na lekcji w gimnazjum wśród upalonych uczniów, (k) - szkolna pogadanka na temat narkotyków, (F) - świadczy o hipokryzji i zakłamaniu oraz $(\mathrm{G})$ jest nieskuteczna i szkodliwa].

Przesłanka: $k$ jest typowym przykładem obiektu, który ma własność $F$, oraz może mieć lub nie mieć wlasności $\mathbf{G}$

[(k) - szkolna pogadanka na temat narkotyków jest typowym przykładem działania profilaktycznego, które (F) - świadczy o hipokryzji i zakłamaniu oraz może być lub nie być $(\mathrm{G})$ - nieskuteczne i szkodliwe].

Wniosek: Generalnie, jeżeli $x$ ma własność $F$, to (zwykle, prawdopodobnie, typowo) $\mathbf{x}$ ma również własność $\mathbf{G}$

[generalnie, jeżeli jakieś x ma własność hipokryzji i zakłamania $(F)$ to zwykle $\mathrm{x}$ jest również szkodliwe i nieskuteczne $(\mathrm{G})]$.

Do tego Schematu z Przykładu Walton podaje propozycje pięciu krytycznych pytań, których zadaniem jest testowanie poprawności użycia danej argumentacji. Po podstawieniu do analizowanego przykładu powinniśmy zatem rozstrzygnąć następujące kwestie:

(KP1) Czy k faktycznie ma własność F i G? (czy rzeczywiście opisana sytuacja w gimnazjum świadczy o hipokryzji i zakłamaniu oraz jest nieskuteczna i szkodliwa).

(KP2) Czy przykład k faktycznie wspiera uogólnienie (ogólny wniosek): czy jest to rzeczywiście przypadek podpadający pod tę generalizację? (czy szkolna pogadanka na temat narkotyków faktycznie jest przykładem podpadającym pod tę generalizację).

(KP3) Czy k jest faktycznie typowym rodzajem przypadków, których dotyczy ta generalizacja? (czy szkolna pogadanka na temat narkotyków jest typowym działaniem profilaktycznym podpadającym pod tę generalizację).

(KP4) W jak szerokim zakresie ta generalizacja znajduje zastosowanie? (w jak wielu wypadkach przyjęta generalizacja ma zastosowanie?).

(KP5) Czy istnieją szczególne okoliczności odnoszące się do k, które osłabiają możliwość generalizacji? (czy istnieją jakieś szczególne okoliczności usprawiedliwiające nieudolność szkolnych pogadanek na temat narkotyków?).

${ }^{23}$ D. Walton, C. Reed, F. Macagno, Argumentation Schemes, Cambridge University Press, New York 2008, s. 308. 


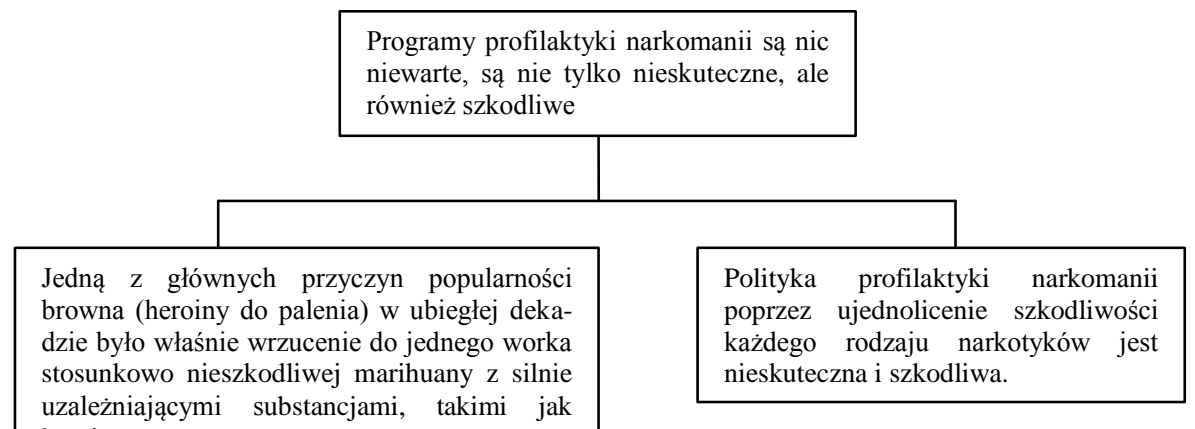

Rys. 2. Diagram - przesłanka 2, schemat od przyczyny do skutku

Na rysunku 2 przedstawiono wizualną reprezentację tego, w jaki sposób przesłanka druga doprowadza do wniosku głównego. Rozumowanie to wpisuje się w Waltonowski schemat od przyczyny do skutku ${ }^{24}$ :

Przesłanka: Generalnie, jeśli wystąpi x, to wystąpi lub może wystąpić y

[Polityka profilaktyki narkomanii poprzez ujednolicenie szkodliwości każdego rodzaju narkotyków (x), jest nieskuteczna i szkodliwa (y)].

Przesłanka: W tym wypadku występuje (lub może wystąpić) x

(nasza polityka zakazuje wszystkich narkotyków, nie rozróżniając ich siły szkodliwości - nie uwzględnia podziału na miękkie i twarde).

Wniosek: W tym wypadku występuje (lub może wystąpić) y

(nasza polityka profilaktyki narkotykowej jest nieskuteczna i szkodliwa). pytania:

Do tego schematu od przyczyny do skutku Walton podaje następujące krytyczne

(KP1) Jak silne jest przyczynowe uogólnienie (jeśli w ogóle jest prawdą)?

(KP2) Czy wymienione dowody (jeśli w ogóle jakiekolwiek istnieją) są wystarczająco silne, aby zagwarantować prawomocność uogólnienia?

(KP3) Czy istnieją inne czynniki, które mogłyby lub będą zakłócać wywołanie efektów w tym przypadku?

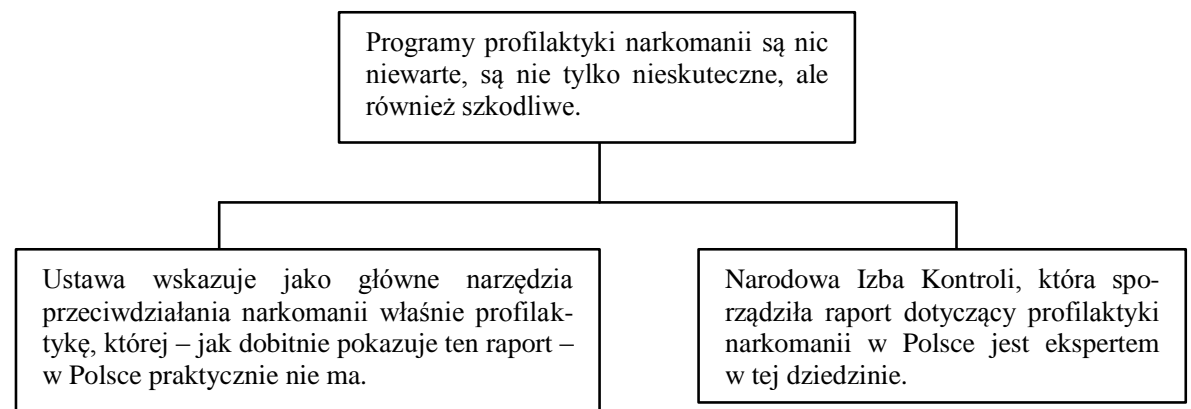

Rys. 3. Diagram - przesłanka 3, schemat z opinii eksperta

${ }^{24}$ Ibidem, s. 312. 
Na rysunku 3 przedstawiono wizualną reprezentację tego, w jaki sposób trzecia przesłanka doprowadza do wniosku głównego. Rozumowanie to wpisuje się w Waltonowski schemat z opinii eksperta ${ }^{25}$. Argumentację przedstawioną przez „Twój Ruch” otrzymuje się przez zastąpienie w schemacie zmiennych x, D oraz A konkretnymi stałymi, czyli w miejsce zmiennej:

- X - należy wstawić „Najwyższą Izbę Kontroli”;

- D - dziedzinę dotyczącą kontroli skuteczności profilaktyki narkomanii w Polsce;

- A - należy zastąpić przez zdanie ,programy profilaktyki narkomanii są nic niewarte, są nie tylko nieskuteczna, ale również szkodliwe".

Schemat z opinii eksperta ${ }^{26}$ :

Przesłanka: Źródło x jest ekspertem w dziedzinie D zawierającej zdanie A.

Przesłanka: x stwierdza, że A (w dziedzinie D) jest prawdziwe (fałszywe).

Wniosek: A może z pewnym prawdopodobieństwem (plausibly) zostać uznane za prawdziwe (fałszywe).

Krytyczne pytania przypisane do tego schematu przedstawiają się następująco:

(KP1) Pytanie dotyczące wiedzy specjalistycznej: Na ile x jest wiarygodny jako źródło wiedzy eksperckiej?

(KP2) Pytanie dotyczące dziedziny: Czy x jest ekspertem w dziedzinie, w której znajduje się A?

(KP3) Pytanie dotyczące opinii: Co stwierdził ekspert x, co by implikowalo A?

(KP4) Pytanie dotyczące wiarygodności: Czy x jest godny zaufania jako źródło?

(KP5) Pytanie dotyczące zgodności: Czy A jest zgodne z tym, co inni eksperci twierdzą?

(KP6) Pytanie dotyczące uzasadnienia: Czy twierdzenie x jest oparte na dowodzie/na jakimś uzasadnieniu? Czy dla twierdzenia $\mathrm{x}$ istnieje jakieś inne dodatkowe uzasadnienie?

- Pierwsze pytanie krytyczne wymaga, aby osoba, na której zdaniu polegamy, była faktycznym ekspertem w danej dziedzinie (tzn. miała odpowiednie kwalifikacje, doświadczenie itd.), a nie jedynie była np. osobą popularną czy sławną. W wypadku Krajowej Izby Kontroli jej kompetencje może weryfikować fakt, że jest organ państwowy powołany właśnie w celu kontroli.

- Drugie pytanie zaleca ostrożność co do możliwości popełnienia błędu ekstrapolacji autorytetu, tzn. rozciągnięcia zakresu czyichś kompetencji na dziedziny, w których ta osoba już kompetencji nie ma. Zatem wątpliwość mógłby budzić fakt, czy dziedzina, w której KIK jest ekspertem, jest adekwatna do poruszanych treści. Zauważmy, że decyzja co do tego, jaka będzie odpowiedź na to pytanie (jak i również na inne pytania), zależeć będzie od subiektywnej oceny osoby analizującej. Nie jest to jednak specyficzna własność metody krytycznych pytań - subiektywność wyboru jest nieunikniona wszędzie tam, gdzie analizowane są teksty z realnych sytuacji komunikacyjnych, a nie abstrakcyjne obiekty, takie jak np. formuły logiczne mające z góry ustalone wartościowanie.

${ }^{25}$ Ibidem, s. 310.

${ }^{26}$ Ibidem, s. 310. 
- Trzecie pytanie sugeruje, że faktyczny sens słów eksperta mógł być przeinaczony. W wypadku raportu KIK można rozważać, czy jego treść została dokładnie zacytowana.

- Czwarte pytanie zawiera wątpliwość, czy ekspert jest osobiście godny zaufania jako źródło informacji. Na przykład istniałaby podstawa do kwestionowania wiarygodności raportu KIK, gdyby był on stronniczy, czyli gdyby KIK coś zyskało przez forsowanie tego twierdzenia.

- Piąte pytanie wiąże się z opiniami „indywidualistów”, szczególnie w zagadnieniach, w których eksperci się nie zgadzają. Pytanie zgodności stawia się zatem przez porównywanie $\mathrm{z}$ innymi znanymi opiniami (i zwłaszcza z jakimiś ekspertami z dziedziny D, głoszącymi inne opinie niż wypowiedź A). W celu przetestowania przykładu wnioskowania z opinii KIK powinniśmy zatem prześledzić opinię na przykład jakichś innych ekspertów $\mathrm{i}$ sprawdzić, czy zgadzają się oni ze stwierdzeniem zawartym w raporcie KIK.

- Ostatnie pytanie wymaga, aby ekspert był w stanie poprzeć swoją opinię obiektywnym dowodem. Można zatem zażądać od KIK wyników badań, testów, jakie zostały przeprowadzone podczas analizy poruszanych kwestii.

W niniejszym rozdziale przedstawiono metodę wizualnej reprezentacji struktury argumentacji nazywaną w teorii argumentacji metodą diagramów. Metoda ta polega na wyróżnieniu poszczególnych komponentów, które składają się na daną wypowiedź argumentacyjną. Pozwala ona opisać i przeprowadzić analizę struktury argumentacji, czyli zależności między jej komponentami. Dodatkowo umożliwia dokładne śledzenie i ocenę każdego z elementów. Metoda diagramów pozwala także przeprowadzić klasyfikację argumentacji pod względem budowy, innymi słowy - umożliwia opisanie schematów argumentacji.

\section{ZAKOŃCZENIE}

W przytoczonych przykładach bardzo wyraźnie widać, że w dyskursie naturalnym, argumentując, nie posługujemy się dokładnie schematami, gdyż w naturalnym języku mamy tendencję do skracania i omijania oczywistych dla nas elementów. Jednakże na podstawie kontekstu i zrozumienia treści wypowiedzi, a także znajomości struktury różnych schematów argumentacji jesteśmy w stanie te rozumowania zrekonstruować, odtworzyć tok rozumowania, co umożliwia przeprowadzenie analizy oraz odpowiedniej oceny argumentacji. Taka analiza języka i argumentacji użytej w dyskursie stanowi podstawę dalszych analiz politologicznych. Umożliwia nam ona ocenę poprawności użytych argumentów, ich siłę, adekwatność, ocenę i określenie strategii osoby wypowiadającej się, a co za tym idzie - określenie przyszłych działań. Daje nam również potężną broń $\mathrm{w}$ walce $\mathrm{z}$ matactwem, kłamstwem i wysuwaniem niepoprawnych wniosków.

W artykule przedstawiono model schematów argumentacji bazujący na propozycji Waltona ${ }^{27}$. Omówiono również podstawowe typy schematów argumentacji, które stanowią propozycję formalnego modelu dla wypowiedzi argumentacyjnych. Ponadto na konkretnym przykładzie zaprezentowano możliwości wizualnej reprezentacji struktury argumentacji, czyli metodę diagramów, utworzono formalną strukturę argumentu -

${ }^{27}$ Ibidem. 
czyli schematy argumentacji, tzw. metoda krytycznych pytań, testowania poprawności zastosowania schematu argumentacji.

Celem niniejszego artykułu było zaproponowanie rozszerzenia metod badań politologicznych o analizę dyskursu naturalnego typu argumentacyjnego. Zastosowanie wyników badań współczesnej teorii argumentacji do badania dyskursu naturalnego politologii znacząco wpłynie na rozwój metodologii badań politologicznych. Zwróci uwagę na problem nieuniknionego wartościowania, podejmowania decyzji oraz niemonotoniczności wyciąganych wniosków. W tym świetle ciekawa staje się próba odpowiedzi na pytanie: czy możliwe jest zastosowanie analizy dyskursu publicznego w obszarze badań politologicznych przy użyciu narzędzi dostarczanych przez teorie argumentacji?

Konkluzje wynikające $\mathrm{z}$ badań zaprezentowanych w niniejszym artykule mogą być przydatne do:

- przedstawienia mechanizmów funkcjonowania komunikowania publicznego, ze szczególnym uwzględnieniem komunikowania politycznego;

- dostarczenia narzędzi wzbogacających metody badań politologicznych o analizę dyskursu naturalnego typu argumentacyjnego (analizy, która wspomoże ustalenie występujących wzorców, wykrycie sprzeczności, ich źródeł oraz przyczyn, a także próby wyciągnięcia wniosków i przewidywań na przyszłość);

- celów dydaktycznych, zwłaszcza w obrębie krytycznego myślenia, teorii argumentacji, komunikacji politycznej.

\section{LITERATURA}

[1] Argumentation Theory: A Very Short Introduction, Argumentation in Artificial Intelligence, eds. I. Rahwan, G. Simari, Springer, Berlin 2009.

[2] Arystoteles, Retoryka, PWN, Warszawa 2008.

[3] Bocheński J.M., Współczesne metody myślenia, ANTYK, Komorów 2009.

[4] Carbogim D., Robertson D., Lee J., Argument-based Applications to Knowledge Engineering, „Knowledge Engineering Review” 15/2 (2000).

[5] Chodubski A.J., Wstęp do badań politologicznych, Wydawnictwo Uniwersytetu Gdańskiego, Gdańsk 2004

[6] Dobek-Ostrowska B., Wiszniowski R., Teoria komunikowania publicznego i politycznego, Astrum, Wrocław 1999.

[7] Fox J., Subrata D.S., Safe and Sound: Artificial Intelligence in Hazardous Appications, Cambridge Mass MIT Press, Cambridge 2000.

[8] Gerstle J., Le communication politique, PUF, Paris 1992.

[9] Grzymała-Kazłowska A., Socjologicznie zorientowana analiza dyskursu na tle współczesnych badań nad dyskursem, „Kultura i Społeczeństwo” XLVIII/1 (2004).

[10] Hastings A.C., A Reformulation of the Modes of Reasoning in Argumentation, Ph.D. Dissertation, Northwestern University, Evanston, III 1963.

[11] Hołówka T., Błędy, spory, argumenty, UW, Warszawa 1999.

[12] http://twojruch.eu/wiadomosci/nik-profilaktyka-narkotykowa-w-szko-achnie-istnieje (dostęp: 20.10.2013).

[13] Jabłońska B., Krytyczna analiza dyskursu: refleksje teoretycznometodologiczne, „Przegląd Socjologii Jakościowej” 2/1 (2006). 
[14] Jemioło T., Dawidczyk A., Wprowadzenie do metodologii badań bezpieczeństwa, Warszawa 2008.

[15] Johnson R. H., Blair T., Logical Self-Defence, Toronto 1977.

[16] Marciszewski W., Podstawy logicznej teorii przekonań, PWN, Warszawa 1972.

[17] Marciszewski W., Sztuka dyskutowania, 4 wyd., Aleph, Warszawa 1996.

[18] Perelman Ch., Olbrechts-Tyteca L., Traite de l'argumentation - la nouvelle rhetorique, PUF, Paris 1958.

[19] Prakken H., Vreeswijk G., Logics for Defeasible Argumentation, Handbook of Philosophical Logic, vol. 4, Kluwer Academic Publishers, Dordrecht 2002.

[20] Szymanek K., Sztuka argumentacji, Słownik terminologiczny, PWN, Warszawa 2001.

[21] Szymanek K., Sztuka argumentacji. Stownik terminologiczny, Wydawnictwo Naukowe PWN, Warszawa 2004.

[22] Tokarz M., Argumentacja, Perswazja, Manipulacja (Argumentation, Persuasion, Manipulation), GWP, Gdańsk 2006.

[23] Toulmin S., The Uses of Argument, Cambridge University Press, Cambridge 1958.

[24] Walton D., Reed C., Macagno F., Argumentation Schemes, Cambridge University Press, New York 2008.

[25] Walton D., Argumentation Schemes for Presumptive Reasoning, LEA, New York 1996.

[26] Walton D., Informal Logic: A Handbook for Critical Argumentation, Cambridge University Press, New York 1989.

\section{DOUGLAS WALTON'S THEORY FOR ARGUMENTATION APPLICABLE TO THE TEST OF POLITICAL COMMUNICATION}

The purpose of this article is methodological evaluation of the usefulness of tools (in the form of argumentation schemes), which provides the contemporary theory of argumentation by Douglas N. Walton applied to research in the field of political communication. It is thus an attempt to answer the question of whether schemes proposed by Douglas $\mathrm{N}$. Walton are possible for use in research in the field of political communication (speech analysis of arguments expressed in natural language) alternative to inadequate and ineffective in this respect tools provided by formal logic. For this purpose, thekey concepts that are the basis for these considerations are described, among others dialogue approach, represented by Jürgen Habermas, which is one of key paradigms of research on political communication and non-monotonic character of the social sciences. Dialogical communication structure is the foundation of argumentative statements, which enables the use of patterns of argumentation as methodological tools to conduct research in this field, and non-monotonicity the core of modern concepts related to the theory of argumentation, including Walton's concept of argumentation schemes. These actions will result in attempting to demonstrate that the analysis of argumentation in the area of communicative behaviours presented in this article can have a significant impact on the development of political research methodology and revision of the existing ways of interpreting them. Conducting research and analysis of argumentative behaviour in the area of political communication is very important for understanding the existing political reality. An application of the results of modern theory of argumentation for studying the natural discourse of political sci- 
ence significantly influences the development of political science research methodology. It draws attention to the inevitable evaluation, decision-making and non-monotonicity of reached conclusions. The theory of argumentation is currently very rapidly developing science and suggests a number of solutions in this field.

Keywords: informal logics, natural discourse, political science research methodology, non-monotonic reasoning.

DOI:10.7862/rz.2016.hss.8

Przesłano do redakcji: czerwiec 2015

Przyjęto do druku: styczeń 2016 